\title{
Prediction of mortality in patients in acute medical wards using basic laboratory and anthropometric data
}

\author{
J. Woo, Y.T. Mak ${ }^{1}$ J. Lau' ${ }^{2}$ and R. Swaminathan ${ }^{3}$
}

Departments of Medicine, ${ }^{1}$ Chemical Pathology and ${ }^{2}$ Center for Clinical Trials and Epidemiological Research, The Chinese University of Hong Kong, Hong Kong, and ${ }^{3}$ Department of Clinical Biochemistry, Guy's Hospital Medical School, London, UK

\begin{abstract}
Summary: The value of anthropometric and biochemical indices in predicting short-term mortality among patients in general medical wards was assessed in 294 patients admitted consecutively to a district hospital over a one month period. Using a stepwise logistic regression model and supported by the linear discriminant analysis method, mortality within 3 months could be predicted with sensitivity of $83 \%$ and specificity of $84 \%$ using the following variables: sex, functional ability, urea, total protein, alkaline phosphatase and albumin-adjusted calcium. Addition of anthropometric values and biochemical nutritional indices did little to improve the accuracy of the prediction, contrary to previous findings among surgical patients and elderly residents of long-term care institutions.
\end{abstract}

\section{Introduction}

Malnutrition is a common finding in hospitalized patients $^{1-7}$ and several studies have shown that nutritional status is an important predictor of prognosis. ${ }^{8-18}$ Many of these studies have been done in surgical patients. ${ }^{11,14-16}$ Buzby et al. ${ }^{11}$ have described a multiparameter index of nutritional status called prognostic nutritional index (PNI) which includes serum albumin, serum transferrin, triceps skin-fold thickness and delayed hypersensitivity skin-test reactivity. PNI predicts postoperative morbidity and mortality. ${ }^{11}$ This index has been subsequently validated in a prospective study of patients undergoing surgery. ${ }^{19,20}$ However, the applicability of this index in other situations has been questioned. ${ }^{21}$

In this study, we have used some nutritional parameters and other routine biochemical and haematological tests to derive a prognostic index applicable to general medical patients.

\section{Subjects and methods}

All patients admitted over a one month period to the general medical wards of a district general

Correspondence: J. Woo, M.D., F.R.C.P., Department of Medicine, Prince of Wales Hospital, Shatin, N.T., Hong Kong.

Accepted: 23 July 1992 hospital were recruited into the study. All subjects were seen by a nurse interviewer, who collected information on the diagnosis of the patients, the subsequent length of hospital stay, and recorded arm anthropometric measurements. Arm circumference was measured at the mid-point between the acromion and olecranon processes. Triceps skinfold thickness was measured with Holtain calipers at the same point. The average of three readings was used. Arm muscle circumference (AMC) was derived from the following equation:

$\operatorname{AMC}(\mathrm{cm})=\operatorname{arm}$ circumference $(\mathrm{cm})$ $\frac{\pi}{10} \times$ triceps skin fold thickness $(\mathrm{mm})$

Corrected arm muscle area (CAMA), was calculated using the following equation as suggested by Heymsfield et al. $^{22}$

$$
\begin{gathered}
\text { Male: CAMA }\left(\mathrm{cm}^{2}\right)=\frac{(\mathrm{AMC})^{2}}{4 \pi}-10 \\
\text { Female: CAMA }\left(\mathrm{cm}^{2}\right)=\frac{(\mathrm{AMC})^{2}}{4 \pi}-6.5
\end{gathered}
$$

The functional ability of each patient (Ability) was also noted. This represented a brief assessment of mobility and activities of daily living, and was graded into three categories: (1) independent; (2) assistance required; and (3) bedridden. Twenty millilitres of venous blood and a random urine sample were collected from each patient in the 
non-fasting state within 48 hours of admission for routine blood tests (complete blood picture, renal and liver function tests) as well as the following: prealbumin, retinol binding protein, transferrin; thiamine, riboflavin and pyridoxine status; serum folate, cyanocobalamin, retinol, vitamin E; plasma copper, zinc and magnesium; and total lymphocyte count. Plasma electrolytes, urea, creatinine, liver function tests, calcium, phosphate and uric acid were estimated by automated methods (Parallel ${ }^{\mathrm{TM}}$ Analyser, American Monitor Corp., Indiana, USA). Urine iodine, potassium, calcium and creatinine were determined on a Astra 8 analyser (Beckman Co. Ltd, CA, USA). An aliquot of plasma was stored at $-70^{\circ} \mathrm{C}$ for batch assay of prealbumin, retinol binding protein, and transferrin by immunoturbidimetric methods using polyclonal antibodies (Dako, Bucks, UK) on a centrifugal analyser (Cobas Bio, Roche Diagnostic, Basle, Switzerland). ${ }^{23}$ Urine total protein, albumin, retinol binding protein and $\mathrm{N}$-acetyl- $\beta$-Dglucosaminidase (NAG) were determined by previously described methods. ${ }^{24}$ Biochemical status of thiamine, riboflavin and pyridoxine was estimated by measurement of red cell coenzyme activities using automated methods. ${ }^{25}$ Cyanocobalamin and serum folate were estimated by a radioimmunoassay method using kits from Diagnostic Products Corporation (LA, CA 90045, USA). Plasma retinol and vitamin $\mathrm{E}$ were measured by a fluorometric method after extraction with hexane. ${ }^{26}$ An aliquot of plasma was stored at $-20^{\circ} \mathrm{C}$ for batch assay of copper, zinc, and magnesium by atomic absorption spectrophotometry, after protein precipitation with trichloroacetic acid to release bound metal ions. Haemoglobin, red cell counts and other red cell parameters, white cell and lymphocyte counts were determined using a Technicon H-6000 haematology analyser (Technicon Instruments Co., Tarrytown, NY, USA).

Data were analysed using the Statistical Package for Social Sciences (Vers. 3.0) and BMDP on an IBM PC. Unpaired Student's $t$-test and MannWhitney $U$-test were used in the comparison of variables between survivors and non-survivors. Multivariate logistic regression analysis was used to arrive at a predictive equation and a prognostic index. Linear discriminant analysis was used as an alternative method to further support the results.

\section{Results}

A total of 294 patients were studied during the one month period. Their age and sex distribution are shown in Table I. Sixty per cent were over the age of 60 years and $64 \%$ of patients stayed in the hospital for less than 7 days. Of the 294 patients, 39 patients died within 3 months. In this group of 39 there were
Table I Distribution of patients studied by sex and age

\begin{tabular}{lcl}
\hline Age group (years) & Number & $F / M$ \\
\hline$<40$ & 63 & $26 / 37$ \\
$40-60$ & 54 & $16 / 38$ \\
$61-80$ & 132 & $61 / 71$ \\
$>80$ & 45 & $30 / 15$ \\
\hline
\end{tabular}

25 males and 14 females, and the mean age of the group was 72.9 ( \pm 11.6 , range $43-95$ years). The mean length of survival was $10.5 \pm 12.8$ days (median 6 days, range 1-61 days). Table II gives the list of diagnoses in this group of non-survivors and in all patients. Some patients have multiple diagnoses.

A total of 60 variables were available. Table III lists the variables that were significantly different between the survivors and non-survivors. Thirtytwo variables were significantly different $(P<0.01)$, eight variables were marginally significantly different $(P<0.05)$ and 14 variables were not different between the two groups $(P>0.05)$. Owing to inadequate sample volume or other technical reasons, results for some measurements were not available in all patients. Furthermore most of these acutely ill patients were bedridden and therefore accurate assessment of height and weight were not available in many patients. The variables where more than 15 values were missing were not included in further analysis (plasma retinol, lymphocyte count, height and weight).

A stepwise logistic regression analysis was then applied based on the variables shown in Table III, with survival and death as the binary outcome. After excluding cases with missing data, 231 cases were included for analysis. The results are sum-

Table II Diagnostic grouping in all patients and in non-survivors

Number (\%)

All patients Non-survivors

\begin{tabular}{lcr}
\hline Gastrointestinal bleeding & $44(15)$ & $4(10)$ \\
Heart failure & $38(13)$ & $3(7.7)$ \\
Infection & $29(10)$ & $12(31)$ \\
Chronic obstructive & & \\
$\quad$ airways disease & $29(10)$ & $3(7.7)$ \\
Cerebrovascular disease & $29(10)$ & $7(18)$ \\
Diabetes mellitus & $21(7)$ & - \\
Hypertension & $18(6)$ & - \\
Malignancy & $9(3)$ & $4(10)$ \\
Others & $79(27)$ & $6(15)$ \\
Total & $296(100)$ & $39(100)$ \\
\hline
\end{tabular}


Table III Variables that were significantly different in subjects who died compared with the 'survivors'

\begin{tabular}{|c|c|c|c|}
\hline & Survived & Died & $P$ value \\
\hline Age (years) & $\begin{array}{l}64.0(255) \\
(16-97)\end{array}$ & $\begin{array}{l}75.0(39) \\
(43-95)\end{array}$ & 0.001 \\
\hline Functional ability & $\begin{array}{l}1.0(255) \\
(1-3)\end{array}$ & $\begin{array}{c}3.0(39) \\
(1-3)\end{array}$ & 0.0001 \\
\hline Mid arm circumference $(\mathrm{cm})$ & $\begin{array}{l}25.0(250) \\
(14-36)\end{array}$ & $\begin{array}{l}24.0(39) \\
(14-34)\end{array}$ & 0.0005 \\
\hline Biceps skinfold thickness (mm) & $\begin{array}{l}5.0(250) \\
(1-64)\end{array}$ & $\begin{array}{l}3.0(39) \\
(1-18)\end{array}$ & 0.0004 \\
\hline Triceps skinfold thickness (mm) & $\begin{array}{c}13.0(250) \\
(2-35)\end{array}$ & $\begin{array}{l}8.0(39) \\
(2-38)\end{array}$ & 0.0003 \\
\hline Arm muscle circumference $(\mathrm{cm})$ & $\begin{array}{c}21.5(250) \\
(12.1-28.9)\end{array}$ & $\begin{array}{c}20.1(39) \\
(12.7-26.2)\end{array}$ & 0.0063 \\
\hline \multicolumn{4}{|l|}{ Corrected arm muscle area $\left(\mathrm{cm}^{2}\right)$} \\
\hline Male & $\begin{array}{l}28.9(133) \\
(6.0-50.2)\end{array}$ & $\begin{array}{l}22.8(25) \\
(5.8-44.6)\end{array}$ & 0.0011 \\
\hline Female & $\begin{array}{l}26.3(117) \\
(5.2-60.0)\end{array}$ & $\begin{array}{c}21.6(14) \\
(6.3-40.1)\end{array}$ & 0.099 \\
\hline Systolic blood pressure (mmHg) & $\begin{array}{l}120.0(250) \\
(60-220)\end{array}$ & $\begin{array}{l}130.0(39) \\
(80-220)\end{array}$ & 0.0138 \\
\hline Plasma urea $(\mathrm{mmol} / \mathrm{l})$ & $\begin{array}{c}7.1(252) \\
(2.3-92.0)\end{array}$ & $\begin{array}{c}14.4(39) \\
(4.4-70.0)\end{array}$ & 0.0001 \\
\hline Plasma creatinine $(\mu \mathrm{mol} / \mathrm{l})$ & $\begin{array}{l}86.0(248) \\
(44-1233)\end{array}$ & $\begin{array}{r}143.0(36) \\
(48-1289)\end{array}$ & 0.0001 \\
\hline Plasma albumin $(g / l)$ & $\begin{array}{l}37.0(245) \\
(10-49)\end{array}$ & $\begin{array}{l}32.5(38) \\
(16-46)\end{array}$ & 0.0001 \\
\hline Plasma alkaline phosphatase (IU/l) & $\begin{array}{l}66.0(252) \\
(23-566)\end{array}$ & $\begin{array}{l}94.5(38) \\
(50-719)\end{array}$ & 0.0001 \\
\hline Total protein $(\mathrm{g} / \mathrm{l})$ & $\begin{array}{c}72.0(246) \\
(11.0-92.0)\end{array}$ & $\begin{array}{c}74.2(39) \\
(45.0-99.0)\end{array}$ & 0.01 \\
\hline Plasma ALT (IU/l) & $\begin{array}{l}12.0(252) \\
(1-1227)\end{array}$ & $\begin{array}{l}18.5(38) \\
(1-1840)\end{array}$ & 0.0059 \\
\hline $\begin{array}{l}\text { Plasma albumin-adjusted calcium } \\
(\mathrm{mmol} / \mathrm{l})\end{array}$ & $\begin{array}{c}2.3(245) \\
(1.53-3.77)\end{array}$ & $\begin{array}{c}2.4(38) \\
(1.43-3.18)\end{array}$ & 0.0005 \\
\hline Plasma phosphate $(\mathrm{mmol} / \mathrm{l})$ & $\begin{array}{c}1.0(253) \\
(0.11-3.11)\end{array}$ & $\begin{array}{c}1.1(38) \\
(0.58-3.10)\end{array}$ & 0.0009 \\
\hline Plasma uric acid (mmol/l) & $\begin{array}{c}0.4(254) \\
(0.14-1.70)\end{array}$ & $\begin{array}{c}0.6(39) \\
(0.20-1.50)\end{array}$ & 0.0001 \\
\hline Plasma glucose $(\mathrm{mmol} / \mathrm{l})$ & $\begin{array}{c}5.8(254) \\
(1.6-36.6)\end{array}$ & $\begin{array}{c}8.4(39) \\
(3.3-31.0)\end{array}$ & 0.0001 \\
\hline Plasma ferritin (pmol/l) & $\begin{array}{l}338.0(254) \\
(15-9450)\end{array}$ & $\begin{array}{l}1117.0(39) \\
(26-9999)\end{array}$ & 0.0000 \\
\hline Plasma vitamin B12 (pmol/l) & $\begin{array}{c}418.0(250) \\
(57-1606)\end{array}$ & $\begin{array}{c}489.5(30) \\
(0-172)\end{array}$ & 0.0002 \\
\hline Plasma folate $(\mu \mathrm{mol} / \mathrm{l})$ & $\begin{array}{c}18.0(250) \\
(4-54)\end{array}$ & $\begin{array}{c}13.5(38) \\
(0-40)\end{array}$ & 0.0022 \\
\hline Plasma transferrin $(\mathrm{g} / \mathrm{l})$ & $\begin{array}{c}2.0(253) \\
(0.40-3.66)\end{array}$ & $\begin{array}{c}1.4(38) \\
(0.58-3.02)\end{array}$ & 0.0001 \\
\hline Plasma prealbumin $(\mathrm{mg} / \mathrm{l})$ & $\begin{array}{c}158.0(253) \\
(30-700)\end{array}$ & $\begin{array}{l}91.0(38) \\
(30-368)\end{array}$ & 0.0020 \\
\hline Plasma retinol* $(\mathrm{mg} / \mathrm{l})$ & $\begin{array}{c}0.44(222) \\
(0.11-1.53)\end{array}$ & $\begin{array}{c}0.31(35) \\
(0.10-1.00)\end{array}$ & 0.0035 \\
\hline Thiamin RBC TK activity (\%) & $\begin{array}{c}8.7(247) \\
(0.1-42.2)\end{array}$ & $\begin{array}{c}12.5(37) \\
(0.3-72.8)\end{array}$ & 0.0011 \\
\hline RBC count $\left(\times 10^{9} / \mathrm{dl}\right)$ & $\begin{array}{c}4.4(245) \\
(1.32-7.28)\end{array}$ & $\begin{array}{c}3.6(38) \\
(2.27-6.32)\end{array}$ & 0.0015 \\
\hline Haemoglobin $(\mathrm{g} / \mathrm{dl})$ & $\begin{array}{l}12.4(245) \\
(3.2-19.5)\end{array}$ & $\begin{array}{c}10.5(38) \\
(5.7-18.9)\end{array}$ & 0.004 \\
\hline Haematocrit & $\begin{array}{c}0.3(245) \\
(0.10-0.55)\end{array}$ & $\begin{array}{c}0.3(38) \\
(0.19-0.53)\end{array}$ & 0.0043 \\
\hline
\end{tabular}


Table III (cont'd)

\begin{tabular}{|c|c|c|c|}
\hline & Survived & Died & $P$ value \\
\hline $\begin{array}{l}\text { Urine total protein/creatinine } \\
\text { ratio }(\mathrm{mg} / \mathrm{mmol})\end{array}$ & $\begin{array}{l}26.8(252) \\
(0.2-445)\end{array}$ & $\begin{array}{c}27.3(38) \\
(1.4-386.7)\end{array}$ & 0.0005 \\
\hline $\begin{array}{l}\text { Urine albumin creatinine ratio } \\
(\mathrm{mg} / \mathrm{mmol})\end{array}$ & $\begin{array}{c}25.5(241) \\
(2.0-974.7)\end{array}$ & $\begin{array}{c}87.8(38) \\
(5.2-910.0)\end{array}$ & 0.0026 \\
\hline $\begin{array}{l}\text { Urine NAG/creatinine ratio } \\
\text { (IU/mmol) }\end{array}$ & $\begin{array}{c}34.5(253) \\
(2.3-899.2)\end{array}$ & $\begin{array}{c}74.7(38) \\
(2.6-615.3)\end{array}$ & 0.0001 \\
\hline $\begin{array}{l}\text { Urine potassium/creatinine ratio } \\
(\mathrm{mmol})\end{array}$ & $\begin{array}{c}4.2(255) \\
(1.01-18.3)\end{array}$ & $\begin{array}{c}4.4(39) \\
(1.77-12.42)\end{array}$ & 0.0059 \\
\hline
\end{tabular}

*Variables not used in the logistic regression analysis. Results are given as median, sample size and range. Significance differences by Mann-Whitney $U$-test. Variables which were not significantly different were: diastolic BP, pulse rate, plasma sodium, potassium, bilirubin, calcium, magnesium, blood HbAl, plasma retinol-binding protein, red cell glutathione reductase and aspartate transaminase activity, $\mathrm{MCV}, \mathrm{MCH}$, urine calcium/creatinine ratio. Variables which were of borderline significance were: plasma copper, plasma zinc, plasma fructosamine, plasma cholesterol, MCHC, WBC count, urine sodium/ creatinine ratio, urine $\mathrm{RBP} / \mathrm{Cr}$.

Table IV Results of stepwise multiple logistic regression using all variables in Table III as inputs

\begin{tabular}{lcccc}
\hline Variables & Coefficient & $\begin{array}{c}\text { Standard } \\
\text { error }(S . E .)\end{array}$ & $\begin{array}{c}\text { Coefficient/ } \\
\text { S.E. }\end{array}$ & P to remove \\
\hline Urea & $0.61 \mathrm{E}-01$ & $0.22 \mathrm{E}-01$ & 2.77 & 0.0032 \\
Albumin-adjusted calcium & 5.13 & 1.63 & 3.15 & 0.0008 \\
Red cell transketolase & $0.70 \mathrm{E}-01$ & $0.28 \mathrm{E}-01$ & 2.47 & 0.0083 \\
$\quad$ activity (RTK) & & & & \\
Total protein & $0.50 \mathrm{E}-01$ & $0.27 \mathrm{E}-01$ & 1.86 & 0.0465 \\
Alkaline phosphatase & $0.76 \mathrm{E}-02$ & $0.35 \mathrm{E}-02$ & 2.15 & 0.0213 \\
Functional ability & 1.52 & 0.34 & 4.43 & 0.0000 \\
Sex & 0.51 & 0.26 & 2.01 & 0.01318 \\
Constant & -23.42 & 5.03 & -4.65 & \\
\hline
\end{tabular}

Notes: (1) Model chi-square $=44.87, \mathrm{df}=7, P<0.0001$. Goodness of fit chi-square (Hosmer-Lemeshow) $=5.078, \mathrm{df}=8, P=0.749$. (2) Classification functions by linear discriminant analysis using the same seven variables:

$D_{\mathrm{S}}=0.516$ urea +111.713 albumin-adjusted calcium +0.967 total protein -0.022 alkaline phosphatase -0.252 functional ability +0.306 red cell transketolase activity +6.532 sex -170.348 .

$D_{\mathrm{D}}=0.610$ urea +116.85 albumin-adjusted calcium +1.001 total protein -0.010 alkaline phosphatase +1.094 functional ability +0.381 red cell transketolase activity +7.541 sex -192.9 .

A subject is classified as belonging to the death group if $D_{\mathrm{D}}>D_{\mathrm{S}}$.

marized in Table IV and the prediction equation is

In $\left(\mathrm{O}_{\mathrm{d}}\right)=0.0613$ (urea) +5.1313 (albumin-adjusted calcium +0.0699 (transketolase activity) +0.0503 (total protein) +0.00757 (alkaline phosphatase) +1.523 (ability) +0.513 (sex) -23.42

where $\mathrm{O}_{d}$ is the odds for death, which is defined as the probability for death given a set of particular prognostic characteristics of the variables included in the model $(P)$, divided by the probability for survival given the same characteristics $(1-P)$. The two sexes are coded as -1 for female and 1 for male. Based on this model, the $\mathrm{O}_{\mathrm{d}}$ was transformed into a conditional probability $\left(P=\mathrm{O}_{\mathrm{d}} /\left(1+\mathrm{O}_{\mathrm{d}}\right)\right.$. $P$ was then used as a prognostic index to predict death as an outcome ${ }^{27}$ for all the subjects in the study. The sensitivities and specificities by different cut-off points were plotted in Figure 1. The two curves intersect at the cut-off of $\boldsymbol{P}$ at 0.12 , yielding equal 
sensitivity and specificity of $80 \%$. The cut-off of $P$ at 0.242 was selected as it gives better specificity $(90.7 \%)$ at the same sensitivity $(80 \%)$.

The model fits the data well and the diagnostic statistics of the residuals (for example, normal probability of the deviances, plots of standardized residuals, leverage and change in coefficients) show no indication of outliners or violation of the model assumptions. Further support of the applicability of the prediction equation and the choice of the cut-off point comes from the reanalysis of the data by an independent statistical method. Using the same subjects, the same set of variables are all significant by discriminant analysis. The classification functions are listed in Table IV, they yield sensitivity of $82.9 \%$ and specificity of $86.3 \%$, which are comparable to the figures given by the prediction equation with the chosen cut-off $(80.0 \%$ and 90.7).

The analysis was repeated using the common biochemical and haematological tests which are routinely done on most if not all patients on admission. Since RTK is not commonly available in routine laboratories, it was omitted. This ensures that the prediction equation has a wider basis for application and further reduces the number of parameters of the equation to six. The number of cases with missing data was also smaller than for Table IV. A total of 258 cases were available for analysis. Table $\mathrm{V}$ gives the results of the stepwise analysis and from this $P$ of 0.175 was chosen as the cut-off value, which corresponds to sensitivity/ specificity of $82.7 \%$ and specificity of $83.9 \%$. Linear discriminant analysis using the same variables gives similar results $(83.8 \% / 84.1 \%)$.

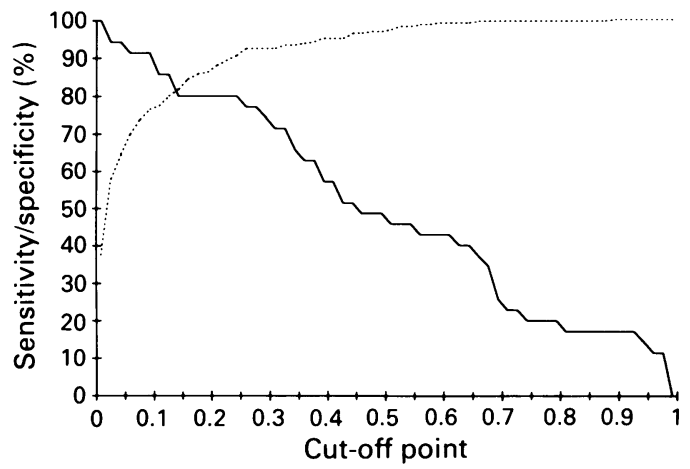

Figure 1 Sensitivity ( - ) and specificity (-.--) of prognostic index at different cut-off values.

We have previously reported a prediction score which was based on elderly living in chronic care institutions. ${ }^{28}$ This score was calculated for the present group of patients and the score was found to be significantly different between survivors and non-survivors $(4.03 \pm 0.22(n=203)$ in survivors vs $2.21 \pm 0.76(n=33)$ in non-survivors). The distribution of this score is given in Table VI and the sensitivity and specificity of the score (a scores value of 0 ) were $27 \%$ and $89 \%$ respectively.

\section{Discussion}

We have previously described the nutritional status of general medical patients ${ }^{29}$ and found poor protein, energy and vitamin status especially in

Table $\mathbf{V}$ Results of stepwise regression model using the 17 'common' variables as inputs

\begin{tabular}{lcccc}
\hline Variables & Coefficient & $\begin{array}{c}\text { Standard } \\
\text { error (S.E.) }\end{array}$ & $\begin{array}{c}\text { Coefficient/ } \\
\text { S.E. }\end{array}$ & P to remove \\
\hline Sex & 0.54 & 0.25 & 2.16 & 0.0155 \\
Functional ability & 1.54 & 0.33 & 4.69 & 0.0000 \\
Urea & $0.68 \mathrm{E}-01$ & $0.20 \mathrm{E}-01$ & 3.44 & 0.0001 \\
Total protein & $0.51 \mathrm{E}-01$ & $0.27 \mathrm{E}-01$ & 1.88 & 0.0353 \\
Alkaline phosphatase & $0.84 \mathrm{E}-02$ & $0.37 \mathrm{E}-02$ & 2.31 & 0.0097 \\
Albumin-adjusted calcium & 3.52 & 1.34 & 2.62 & 0.0034 \\
Constant & -19.01 & 4.33 & -4.39 & \\
\hline
\end{tabular}

Notes: (1) Common variables included were age, sex, ability, systolic blood pressure, urea, creatinine, total protein, albumin, alkaline phosphatase, ALT, albumin adjusted calcium, phosphate, uric acid, glucose, red cell count, haemoglobin and haematocrit. (2) Model chi-square $=41.53, \mathrm{df}=6, P<0.0001$. Goodness of fit chi-square (Hosmer-Lemeshow) $=5.917$, $\mathrm{df}=8, P=0.657$. (3) Classification functions by discriminant analysis using the same six variables:

$D_{\mathrm{s}}=0.627$ urea +104.433 albumin-adjusted calcium +0.960 total protein -0.024 alkaline phosphatase +0.099 functional ability +6.328 sex -160.737 .

$D_{\mathrm{d}}=0.734$ urea +108.782 albumin-adjusted calcium +0.988 total protein -0.013 alkaline phosphatase +1.565 functional ability +7.400 sex -180.642 .

A subject is classified as belonging to the death group if $D_{\mathrm{d}}>D_{\mathrm{s}}$. 
Table VI Distribution of discriminant function score (Woo et al., 198928) in survivors and non-survivors

\begin{tabular}{lccc}
\hline Score & $\begin{array}{c}\text { Number of subjects } \\
\text { Alive at } \\
\text { 3 month }\end{array}$ & $\begin{array}{c}\text { Death at } \\
\text { 3 month }\end{array}$ & $\begin{array}{c}\text { \% of subjects } \\
\text { who had died }\end{array}$ \\
\hline-2.5 & 5 & 4 & 44 \\
0 & 17 & 5 & 23 \\
2.5 & 43 & 10 & 19 \\
5.0 & 57 & 7 & 11 \\
7.5 & 56 & 3 & 5 \\
10.0 & 20 & 3 & 13 \\
$>10.0$ & 5 & 1 & 17 \\
\hline
\end{tabular}

those over 60 years of age. In the present study, we have examined the differences between those who died within 3 months and those who survived in an attempt to derive a prognostic index. Not surprisingly variables which are indicative of protein calorie malnutrition such as skinfold thickness, arm muscle circumference, plasma albumin, transferrin and prealbumin were significantly lower in non-survivors (Table III). In addition, plasma urea, creatinine and albumin-adjusted calcium were also significantly different, possibly reflecting the higher proportion of patients in medical wards with renal failure or neoplasm contributing to short-term mortality. When these many variables were included in the logistic regression analysis, none of the anthropometric measurements contributed to the prediction. This is in contrast to the studies in surgical patients $s^{7,11,12,17}$ and agrees with our previous study in elderly living in chronic care institutions $^{28}$ and with other studies especially those in the elderly..$^{10,30}$

When all the variables were included in the analysis, the nutritional parameter which contributed to the prediction model was thiamine status (percentage activation of red cell transketolase). None of the other nutritional parameters (for example, albumin, transferrin, prealbumin, plasma, copper, zinc, etc.) were found to be of significance. This finding is different from our previous observation in the elderly ${ }^{29}$ and from other reports. ${ }^{7,8,10,12,13}$ There are differences in the characteristics of the patient population in different settings. Infection is a common cause of mortality among surgical patients and elderly residents of long-term care institutions, and nutritional status is important in determining the susceptibility to infection and the outcome. ${ }^{31}$ Among patients in acute medical wards, there is probably a larger proportion with endstage disease such as renal and liver failure, or malignancy. This may account for the inclusion of urea, alkaline phosphatase, and plasma calcium as predictor variables in medical patients and not in surgical or long-term care institutional patients. This study highlights the need for different prognostic indices for different patient population groups.

In our previous study of elderly subjects in chronic care institutions apart from nutritional markers (transferrin, prealbumin and haemoglobin), fructosamine and glycosylated haemoglobin were found to predict mortality. ${ }^{28}$ In this present study, data were available in 236 patients (203 survivors and 33 non-survivors). When the score derived from the previous study was applied to this group of patients, although it was significantly lower in non-survivors, the sensitivity was poor $(27 \%)$. Using predictors consisting of functional ability, albumin-adjusted calcium, plasma urea, thiamine status, alkaline phosphatase, sex and total protein in that order, a much higher sensitivity (when a cut-off value of 0.242 was used) of $80 \%$ was obtained. When we reanalysed the data using only simple haematological and biochemical data, the resulting equation was equally good. Therefore, among patients in acute medical wards, a combination of simple bedside observations and routine biochemical tests are sufficient for predicting shortterm mortality. Anthropometry and expensive biochemical tests are not needed. However, this does not imply that the nutritional status of these patients can be neglected, as this study only examines short-term mortality; other outcomes such as length of recovery, readmission frequency, or general well-being after discharge which may well be affected by nutritional status ${ }^{32}$ were not examined.

\section{Acknowledgement}

We would like to thank all our colleagues for giving permission to study patients under their care. We also thank Miss S.M. Chan, registered nurse for her help with the study, Mr Robert Cheung for help with some of the protein measurements and Mrs Angela Chu for typing the manuscript.

\section{References}

1. Bistrian, B.R., Blackburn, G.L., Hallowel, E. \& Heddle, R. Protein status of general surgical patients. JAMA 1974, 230: 858-860.
2. Wood, B., Kelleher, D., Lo, L. et al. Nutritional status in hospital inpatients: implications for nutritional support services. Aust NZ J Med 1985, 15: 435-441. 
3. Bistrian, B.R., Blackburn, G.L., Vitale, J. \& Cockrane, D. Prevalence of malnutrition in general medical patients. JAMA 1976, 235: 1567-1570.

4. Hill, G.L., Pickford, I., Young, G.A. et al. Malnutrition in surgical patients. An unrecognised problem. Lancet 1977, 1: 689-692.

5. Steffee, W.P. Malnutrition in hospitalized patients. JAMA 1980, 244: 2630-2635.

6. Elmstähl, S. Hospital nutrition in geratric long-stay medicine, Thesis, University of Lund, Sweden, 1987.

7. Dempsey, D.T., Buzby, G.P. \& Mullen, J.L. Nutritional assessment in the seriously ill patient. J Am Coll Nutr 1983, 2: 15-22.

8. Lowe, E.F., Stein, M., Woolley, T., Waycaster, M. et al. Prognostic nutritional index: its usefulness as a predictor of clinical course. J Am Coll Nutr 1983, 2: 231-240.

9. Freeman, M., Frankmann, C., Beck, J. \& Valdivieso, M. Prognostic nutrition factors in lung cancer patients. JPEN 1982, 6: $122-127$.

10. Harvey, K.B., Moldawer, L.L., Bistrian, B.R. \& Blackburn, G.L. Biological measures for the formulation of a hospital prognostic index. Am J Clin Nutr 1981, 34: 2013-2022.

11. Buzby, G.P., Mullen, J.L., Matthews, D.C., Hobbs, C.L. \& Rosato, E.F. Prognostic nutritional index in gastrointestinal surgery. Am J Surg 1980, 139: 160-167.

12. Phillips, $\mathbf{P}$. Grip strength, mental performance and nutritional status as indicators of mortality risk among female geriatric patients. Age Ageing 1986, 15: 53-56.

13. Bozzetti, F., Migliavacca, S., Gallus, G. et al. 'Nutritional' markers as prognostic indicators of postoperative sepsis in cancer patients. JPEN 1985, 9: 464-470.

14. Leite, J.F., Antunes, C.F., Monteiro, J.C. \& Pereira, B.T. Value of nutritional parameters in the prediction of postoperative complications in elective gastrointestinal surgery. Br J Surg 1987, 74: 426-429.

15. Bland, B.D. \& Shoemaker, W.C. Probability of survival as a prognostic and severity of illness score in critically ill surgical patients. Crit Care Med 1985, 13: 91-95.

16. Braga, M., Baccari, P., Scaccabarozzi, S. et al. Prognostic role of preoperative nutritional and immunological assessment in the surgical patient. JPEN 1988, 12: 138-142.

17. Kalfarentzos, F., Spiliotis, J., Velimezis, G., Dougenis, D. \& Androulakis, J. Comparison of forearm muscle dynamometry with nutritional prognostic index, as a preoperative indicator in cancer patients. JPEN 1989, 13: 34-36.

18. Kudlackova, M., Andel, M., Hajkova, H. \& Novakova, J. Acute phase proteins and prognostic inflammatory and nutritional index (PINI) in moderately burned children aged up to 3 years. Burns 1990, 16: 53-56.
19. Smale, B.F., Mullen, J.L., Buzby, G.P. \& Rosato, E.F. The efficacy of nutritional assessment and support in cancer surgery. Cancer 1981, 47: 2375-2381.

20. Goodwin, W.J. Jr \& Torres, J. The value of the prognostic nutritional index in the management of patients with advanced carcinoma of the head and neck. Head Neck Surg 1984, 6: 932-937.

21. Jones, T.N., Moore, E.E. \& Vanway, C. Factors influencing nutritional assessment in abdominal trauma patients. JPEN 1983, 7: 115-116.

22. Heymsfield, S.B., McManus, C., Smith, J., Stephens, V. \& Nixon, D.W. Anthropometric measurement of muscle mass: revised equations for calculating bone-free muscle mass area. Am J Clin Nutr 1982, 36: 680-690.

23. Cheung, C.K. \& Swaminathan, R. Automated immunoturbidimetric methods for the determination of retinol binding protein, prealbumin and transferrin in urine. Clin Biochem 1989, 22: 425-427.

24. Cheung, C.K., Yeung, V.T.F., Cockram, C.S. \& Swaminathan, R. Urinary excretion of albumin and enzymes in non-insulin-dependent Chinese diabetes. Clin Nephrol 1990, 34: 125-130.

25. Mak, Y.T. \& Swaminathan, R. Assessment of vitamin $B_{1}, B_{2}$ and $B_{6}$ status by coenzyme activation of red cell enzymes using a centrifugal analyser. J Clin Chem Clin Biochem 1988, 26: $213-217$

26. Woo, J., Ho, S.C., Mak, Y.T., Shek, C.C. \& Swaminathan, R. Vitamin A and E status in healthy elderly Chinese in Hong Kong. Eur J Clin Nutr 1988, 42: 689-695.

27. Brown, B.W. Jr. Prediction analysis for binary data. In Miller, R.G., Efron, B., Brown, B.W. \& Moses, L.W. (eds) Biostatistics Casebook. Wiley, New York, 1980.

28. Woo, J., Chan, S.M., Mak, Y.T. \& Swaminathan, R Biochemical predictors of short term mortality in elderlyo residents of chronic care institutions. J Clin Path 1989, 42. $1241-1245$.

29. Woo, J., Mak, Y.T. \& Swaminathan, R. Nutritional status of general medical patients. Influence of age and disease. $J$ Nutr Biochem 1991, 2: 274-280.

30. Kergoat, M.-J., Leclere, B.S., Petit Clerc, C. \& Imback, A. Discriminant biochemical markers for evaluating the nutritional status of elderly patients in long term care. Am J Clin Nutr 1987, 46: 849-861.

31. Chandra, R.K. Nutritional regulation of immunocompetence and risk of infection in old age. Immunology 1989, 67: $141-147$

32. Williams, C.M., Lumbers, M. \& Driver, L.T. Nutritional demands during rehabilitation from acute illness. Geriat $\mathrm{Med}$ 1990, 20: 13-16. 